Volume 7, No. 11 November 2019

International Journal of Emerging Trends in Engineering Research

Available Online at http://www.warse.org/IJETER/static/pdf/file/ijeter427112019.pdf

https://doi.org/10.30534/ijeter/2019/427112019

\title{
Performance Analysis Of Low Pullin Voltage RF MEMS Switch For Reconfigurable Antenna Applications
}

\author{
N. Siddaiah ${ }^{1}$, B. Sri Keerthana Reddy ${ }^{2}$, B. Manoj Kumar ${ }^{3}$, K. Raja Sekhar ${ }^{4}$,G. Venkata Ganesh ${ }^{5}$ \\ ${ }^{1}$ Associate Professor, Koneru Lakshmaiah Education Foundation, Vaddeswaram- 522302, AP, India \\ ${ }^{2,3,4}$ UG Students, Koneru Lakshmaiah Education Foundation, Vaddeswaram- 522302, AP, India \\ ${ }^{5}$ Assistant Professor, Koneru Lakshmaiah Education Foundation, Vaddeswaram- 522302, AP, India
}

\begin{abstract}
Micro Electromechanical System also popularly known as MEMS is a technique of combining both mechanical and electrical components to produce a miniature device. The functionality of MEMS devices are mechanical and electrical functions. MEMS has number of micro components integrated on one single chip it is done in such a way to sense and control the environment at the same time. The integration of these chips is done by using micro fabrication technologies. There are few parameters
\end{abstract}

Low Actuation is achieved by using electrostatic mechanism. The proposed RF MEMS switch works at a low pull in voltage at $17 \mathrm{~V}$ is achieved by electromechanical analysis. The Proposed switch has a capacitance ratio of 159 . Electromagnetic analysis is analyzed, and RF performance of the switch is discussed.

Key words: Low pull in voltage, Return loss, RF switch

\section{INTRODUCTION}

Over the last few years, a rapid change in MEMS field took place which lead to the design of miniature devices with high transfer speed and reduced actuation voltages [1-3]. MEMS systems incorporate advantages and overcome switch drawbacks such as waveguiding, half- conductor switching devices [4-7].

In correspondence applications, RF MEMS switchs are the choice for substituting traditional switches. These traditional switches decrease radio frequency performance like loss of insulation, loss of insertion and loss of signals over $1 \mathrm{GHz}$ [8]. The devices created by MEMS technology are widely used in communication field. The RF characteristics of the switch is varied from application to application [9-11]. Contact switches finds their applications in RF communication systems for routing RF signal through right antenna by switching between transmitter and receiver, routing signal to different blocks in multiband systems [1214].Among all MEMS devices switches increase a consideration as a result of their favorable circumstances [15]. There better way to avoid the contact of metal and metal is to design a capacitive switch [16-18]. With no actuation DC voltage, capacitance formed is very small (10-
100fF), which do not affect impedance of signal line and thus, switch simply acts here as an ON state causing RF signal to pass through transmission line from one end to another end [19].

Dual electrode capacitive shunt switch two electrodes on both sides of the switch and near to central signal line of the switch [20-22].

Extremely great seclusion, less addition misfortune, smaller size of the device in this way the device size is small [23-25]. The parameters like pull in voltage, isolation, and return loss are mentioned. They are mainly applicable to antenna applications and filters [26]. The modelling of switch and performance analysis of switch has taken place [27-28]. And to find the best design metrics, the values of beam thickness, width, conductor and dielectric materials are varied and verified [29-30]. This is the basis to finalize the switch parameters. Evaluation of the output of RF parameters takes place with the help of HFSS Software. The layout of the paper is as follows: Section - II describe the structure and concept evaluation of the switch. Section - III covers discussions and results of the model. Section- IV covers the conclusion.

\section{THE PROPOSED SWITCH ANALYSIS}

Silicon substrate has a dielectric value of 11.68 Oxide Layer, silicon oxide has a dielectric value of 3.9. Oxide layer is placed on substrate. Silicon Nitride, has a dielectric value of 7 .

\section{SWITCH DIMENSIONS:}

Table 1: Dimensions of the proposed switch

\begin{tabular}{|l|l|l|}
\hline SNo & Structural Element & Values \\
\hline 1. & Thickness of Substrate & 20 \\
\hline 2. & $\begin{array}{l}\text { Thickness of Ground and signal } \\
\text { line }\end{array}$ & 15 \\
\hline 3. & Thickness of Dielectric layer & 0.1 \\
\hline 4. & Thickness of Oxide layer & 10 \\
\hline
\end{tabular}




\begin{tabular}{|l|l|c|}
\hline 5. & Length of beam & 300 \\
\hline 6. & Width of the beam & 150 \\
\hline 7. & Thickness of the beam & 0.5 \\
\hline 8. & Air gap & 2 \\
\hline
\end{tabular}

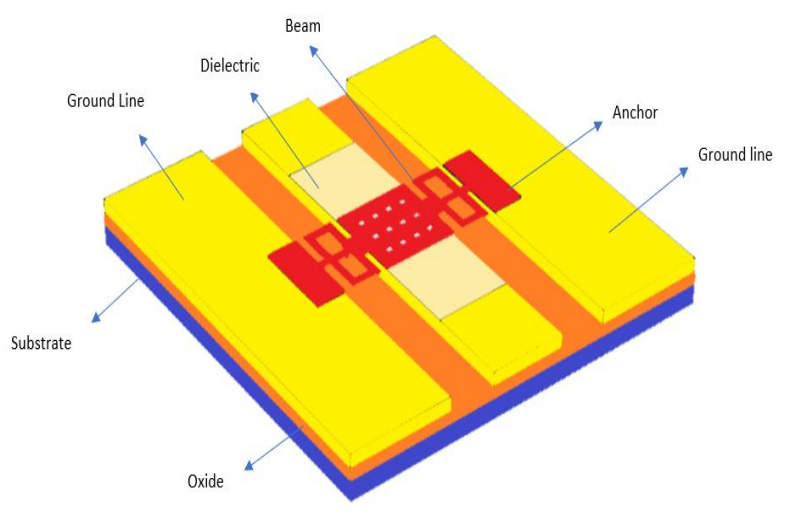

Figure 1:Proposed Switch Schematic

\section{A. SPRING CONSTANT(K):}

Without any residual stress for shunt switch the spring constant value is given by

$$
\mathrm{K}=32 * \mathrm{E}^{*} \mathrm{w}\left(\frac{t}{l}\right) 3
$$

Spring constant general expression is

$$
\mathrm{K}=32 * \mathrm{E} * \mathrm{w}\left(\frac{t}{l}\right) 3+8 \sigma(1-\mathrm{V}) \mathrm{w}\left(\frac{t}{l}\right)
$$

Where $\mathrm{t}=$ the thickness of the beam,

$$
\begin{aligned}
& \mathrm{l}=\text { length of the beam, } \\
& \mathrm{w}=\text { width of the beam and } \\
& \mathrm{V}=\text { Poisson's ratio }
\end{aligned}
$$

For a shunt switch the layer is fastened one side it doesn't contain pressure.

$\sigma=$ Axial stress $(\mathrm{Pa})$

\section{B. ACTUATION VOLTAGE:}

When voltage is applied electrostatic force is induced between the beam and electrodes. Based on the voltage the beam tends to deflect. The minimum voltage required to deflect the beam is called as actuation voltage.

$V_{p}=\sqrt{\frac{8 k g_{0}{ }^{3}}{27 \varepsilon_{0} A}}$

Here g0 = Air gap

$$
\begin{aligned}
& \varepsilon 0=\text { Free space permittivity } \\
& \mathrm{k}=\text { Spring Constant } \\
& \mathrm{A}=\mathrm{W}^{*} \mathrm{~W}
\end{aligned}
$$

$\mathrm{w}=$ Width of the beam

$\mathrm{W}=$ Signal line width

\section{MECHANICAL RESONANT FREQUENCY:}

The mechanical spring is given by

$$
\omega 0=\sqrt{\frac{K}{m}}
$$

\section{SWITCHING TIME:}

The period to change from on to off state is known as toggling time and inversion of toggling time is speed.

$$
T s=\frac{3.67 V_{p}}{V_{s} \omega_{0}}
$$

Where $\mathrm{Vp}=$ Minimum Voltage requires to on the switch

$$
\begin{aligned}
& \text { Vs }=\text { Supply voltage, } \\
& \text { Vs }=1.4 \mathrm{Vp}
\end{aligned}
$$

\section{E. CAPACITANCE OF THE SWITCH:}

The Capacitance of the switch can be improved. This can be achieved by changing the on and off state capacitance.

\section{F. UPSTATE CAPACITANCE:}

Upstate capacitance $(\mathrm{Cu})$ can be expressed as:

$$
\mathrm{C}_{\mathrm{on}}=\frac{\varepsilon_{0} W w}{g+\frac{t_{d}}{\varepsilon_{r}}}
$$

\section{G. DOWNSTATE CAPACITANCE:}

When voltage is applied to the switch, it deflects and comes to downstate. This is called as off state capacitance (Coff)is given as:

$$
\mathrm{C}_{\mathrm{off}}=\frac{\varepsilon_{0} \varepsilon_{r} W w}{t_{d}}
$$

\section{H. CAPACITANCE RATIO:}

Downstate to upstate capacitance is ratio of capacitance and is given as

$$
\mathrm{C}_{\text {ratio }}=\frac{C_{o f f}}{C_{o n}}
$$

\section{THEORETICAL VERIFICATION OF THE PROPOSED SWITCH:}

Table 2: Theoretical verification of the proposed switch

\begin{tabular}{|c|c|}
\hline Parameters & Value \\
\hline Spring Constant value & 8.9 \\
\hline Actuation voltage & $15.43 \mathrm{~V}$ \\
\hline Switching Time & $29.7 \mu \mathrm{s}$ \\
\hline Upstate Capacitance & $0.04397 \mathrm{pF}$ \\
\hline Downstate Capacitance & $6.99 \mathrm{pF}$ \\
\hline Capacitance Ratio & 158.9 \\
\hline
\end{tabular}




\section{RESULTS AND DISCUSSIONS}

\section{ELECTROMECHANICAL PERFORMANCE AND ANALYSIS OF PROPOSED RF MEMS SWITCH:}

The proposed switch is designed and simulated in COMSOL Multi Physics. Parameters like Air gap, beam width, beam thickness, dielectric materials, conducting materials are analyzed and plotted. In order to design a low pull in voltage switch these parameters needs to give a high deflection.

\section{A. ANALYSIS OF AIRGAP ON SWITCH:}

The figure 2 shows the graphs of displacement vs voltage, by varying the airgaps. The airgaps is varied between 1 to $3 \mu \mathrm{m}$. But during fabrication a minimum of $2 \mu \mathrm{m}$ airgap is suggestable.

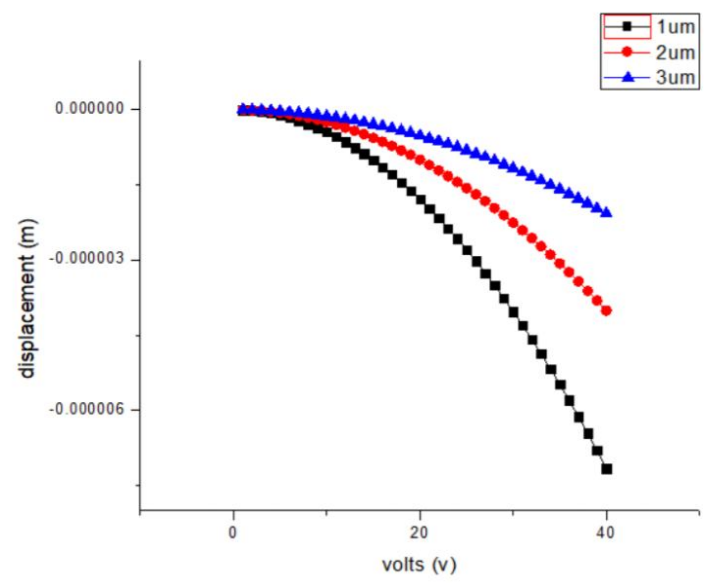

Figure 2: Deflection graph obtained by varying the airgaps

\section{B. SELECTION OF BEAM THICKNESS OF THE SWITCH BASED ON HIGH DEFLECTION:}

The figure 3 displays the deflection occurred by varying the thickness of the beam. At $0.5 \mu \mathrm{m}$ the switch has more deflection and low pull in voltage compared to others.

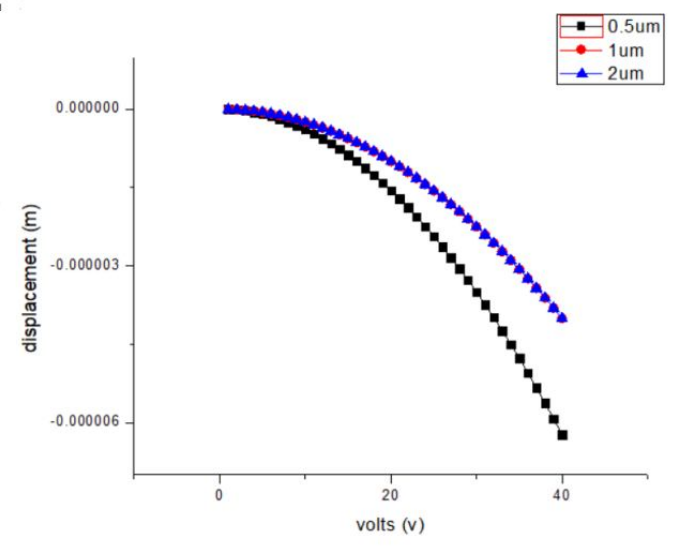

Figure 3: Deflection graph obtained by varying thickness of the beam.

\section{SELECTION OF BEAM WIDTH OF THE SWITCH BASED ON HIGH DEFLECTION:}

To select the beam width for the switch, make the length and thickness of the beam to be constant and vary the beam width. Fig. 4 shows the graphs of displacement vs voltage for varying beam width. Pull in voltage and beam width are inversely proportional to each other from the equation (2). From the Fig. 4 beam width with $150 \mu \mathrm{m}$ has a high deflection compared to others.

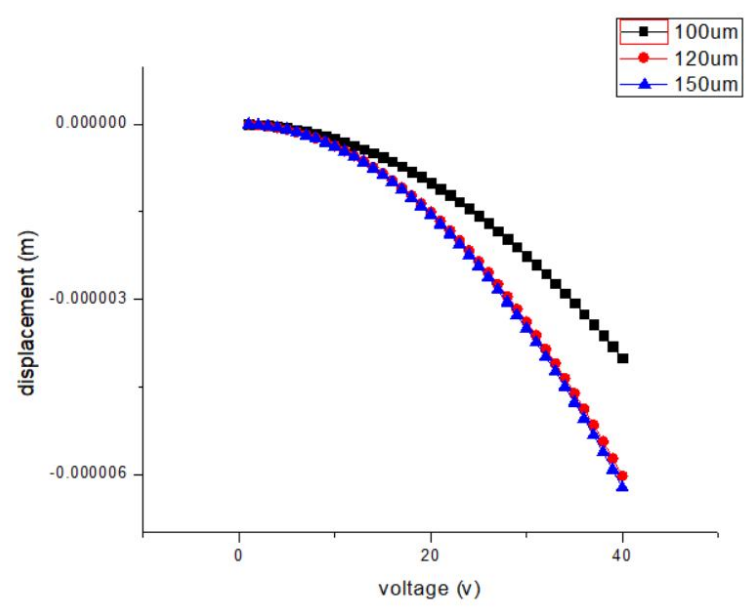

Figure 4: Deflection graph obtained by varying width of beam

\section{SELECTING THE CONDUCTORS BASED ON DEFLECTION FOR THE SWITCH:}

To obtain good performance of a switch, a proper conductor should be chosen. From the figure 5 we can say that gold has high deflection hence gold will be the conductor of the switch.

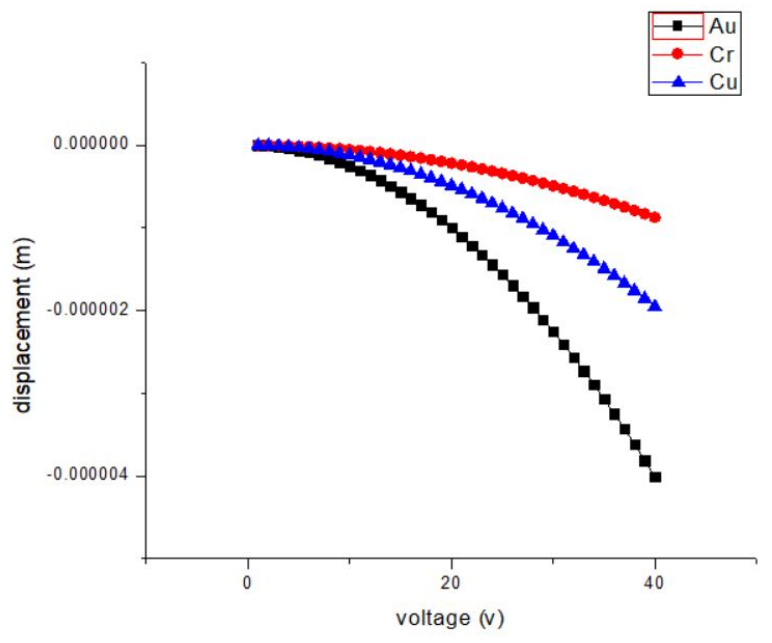

Figure 5: Displacement graphs obtained for different conducting materials. 


\section{E. EFFECT OF DIFFERENT DIELECTRICS ON SWITCH:}

From the Fig. 6 we observe that $\mathrm{Si}_{3} \mathrm{~N}_{4}$ gives a better deflection compared to $\mathrm{ZnO}$.

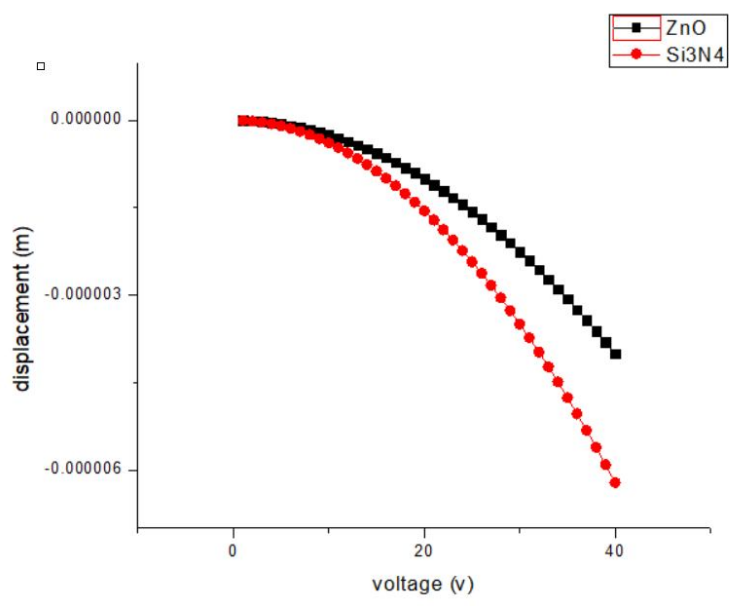

Figure 6: Different Dielectrics Deflection

\section{F. DETERMINING SWITCHING TIME:}

Switching time depends on $\mathrm{Vp}$, w0 and Vs from the formula mentioned in equation (4) mentioned above. Fig 6 explains about the change in voltage with respect to switching time of the switch. The Switching time of the proposed switch observed as $29.7 \mu$ s at pull-in voltage $15.43 \mathrm{~V}$.

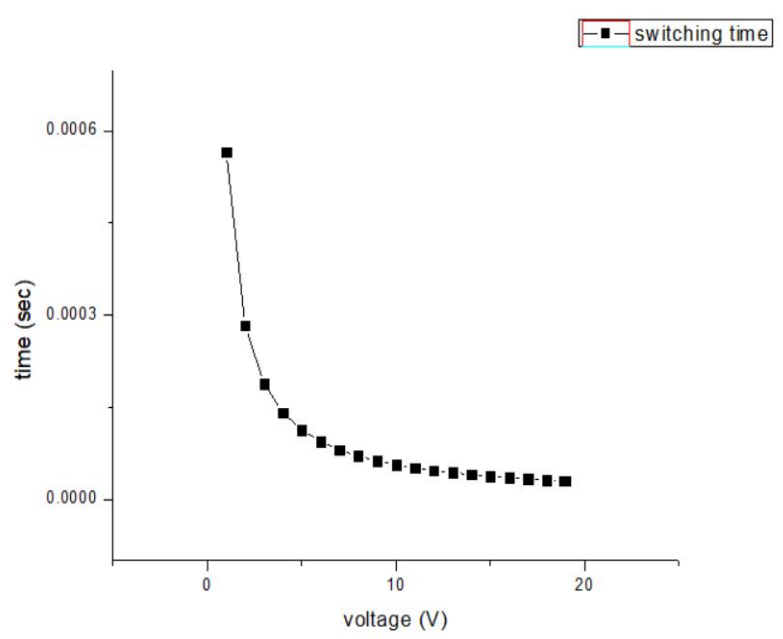

Figure 7: Switching time vs source voltage

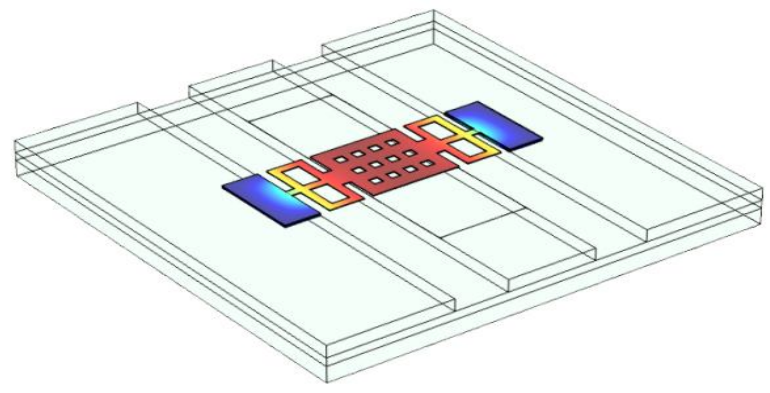

Figure 8: Proposed RF MEMS Switch

\section{ELECTROMAGNETIC AND RF PERFORMANCE OF THE SWITCH}

The electromagnetic analysis tells about Radio Frequency analysis of RF MEMS switch in decibels. The Parameters which gives the analysis of RF MEMS Switch is Isolation, Insertion loss and Return loss. Return loss is analyzed in both $\mathrm{ON}$ and OFF condition, Insertion loss is analyzed in ON state and Isolation is analyzed in OFF state. There is an air gap of $3 \mu \mathrm{m}$ gap with dielectric material as silicon nitride. Here, $0-10 \mathrm{GHz}$ range of frequency is measured.

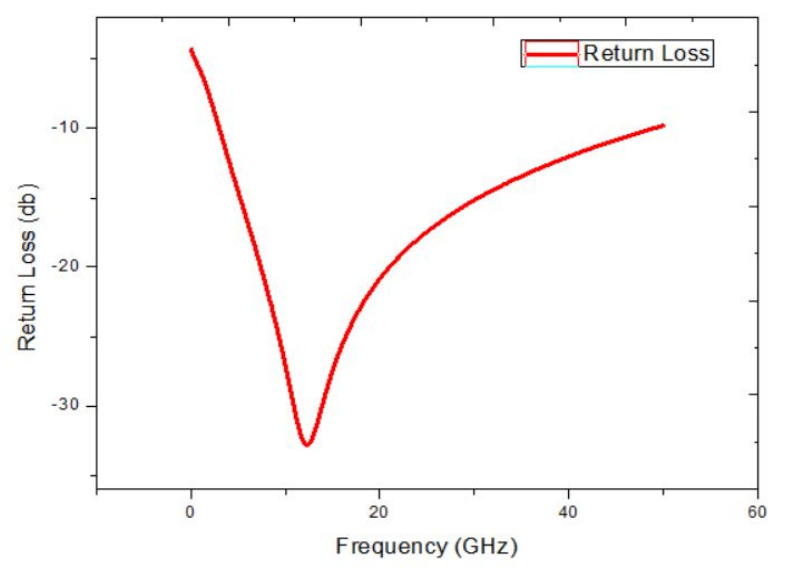

Figure 9: Return loss(S11) of proposed switch [ON State]

The electromagnetic simulation takes place at $0-10 \mathrm{GHz}$ and the parameters are evaluated. In ON state of the switch a return loss of -5 to $-35 \mathrm{~dB}$ is shown in fig. 8 and fig. 9 displays an insertion loss of -0.01 to $-0 . .5 \mathrm{~dB}$. 


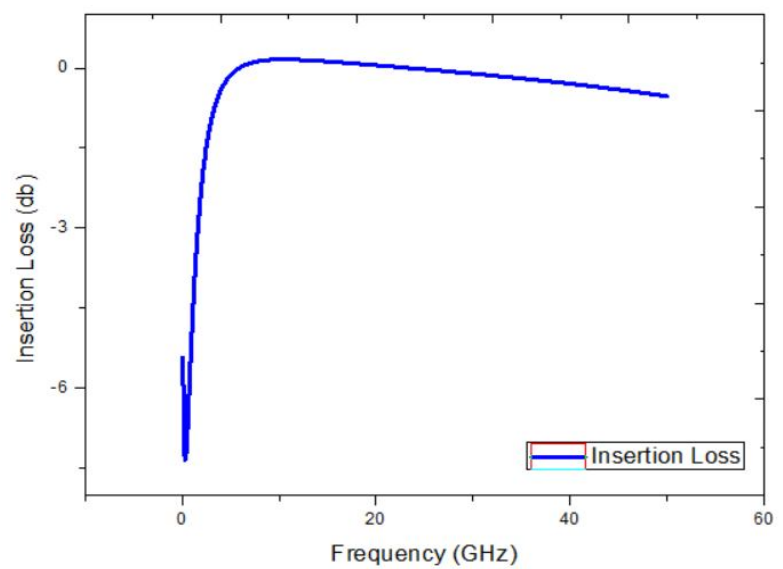

Figure 10: Insertion loss(S21) of proposed switch[ON State]

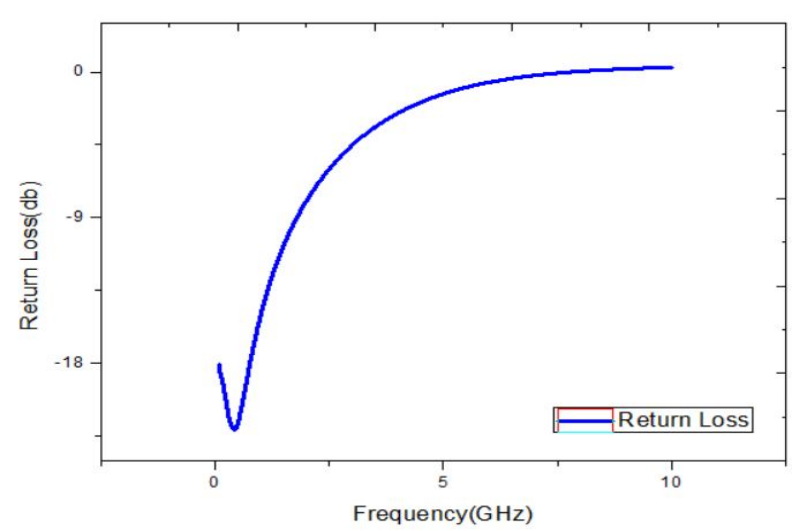

Figure 11: Return loss(S11) of proposed switch [OFF State]

In Fig. 10, a return loss of -1 to $-27 \mathrm{db}$ is observed in OFF state of switch and Fig. 11 shown below displays a isolation loss of -1 to $-18 \mathrm{db}$ in OFF state.

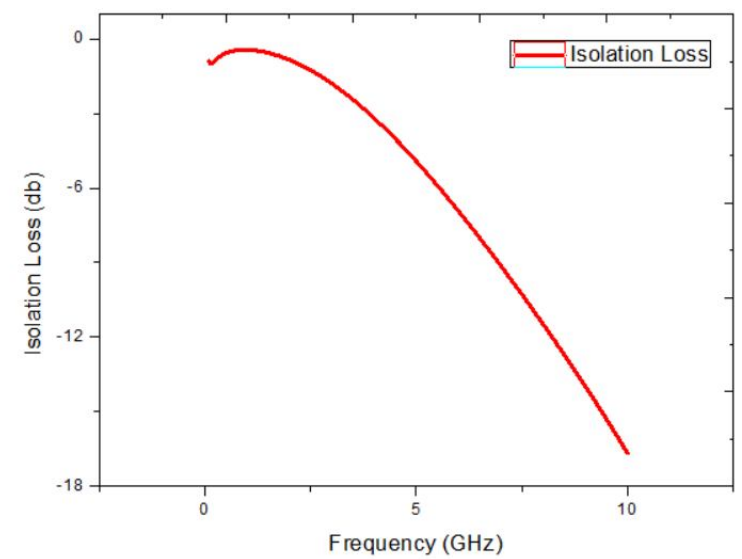

Figure 12:. Isolation loss(S21) of proposed switch[OFF State]

\section{CONCLUSION}

In this paper, a low actuation voltage switch is modelled with electromagnetic and electromechanical properties analysis. It is designed with a function of different parameters. By the observation from the graphs during the ON state of return loss it has a less than -35 decibels and the insertion loss in ON state is higher than -0.1 decibels at $10 \mathrm{GHz}$ frequency. The Isolation in its OFF state has higher than -16 decibels at $10 \mathrm{GHz}$ frequency. The Proposed switch has a capacitance ratio of 159 . The designed switch shows excellent RF characteristics and can be highly useful in reconfigurable antenna applications.

\section{REFERENCES}

[1].Sharma A, Shah A, Bharti R (2015) Design and simulation of lowactuation voltage perforated shunt RF MEMS switch. Int J EngTech Res 3(6). ISSN 2321-0869

[2].Montserrant Fernandez-Bolanos Badia, Elizabeth Buitrago, and Adrian Mihai Ionescu,2012, "RF MEMS shuntCapacitive Switches Using AIN", IEEE Journal Of Microelectromechanical Systems, vol. 21, no.5. https://doi.org/10.1109/JMEMS.2012.2203101

[3].Angira M, Sundaram GM, Rangra K, Bansal D, Kaur M (2013), Onthe investigation of an interdigitated, high capacitance Ratioshunt RF-MEMS switch for X-band applications. In: Proceed-ings of NSTI nanotechnology, Washington 2, pp 189-192.

[4].M.olaei S, Ganji BA (2016) Design and simulation of a novel RFMEMS shunt capacitive switch with low actuation voltage and high isolation. Springer-Verlag, Berlin Heidelberg

https://doi.org/10.1007/s00542-016-2923-2

[5].N.Siddaiah,et.al, "Design, Simulation and Performance Analysis of Novel Cantilever Rf-Mems Switch Using Serpentine Meanders" International Journal of Engineering and Advanced Technology (IJEAT) ISSN: 2249 - 8958, Volume-8 Issue-4, April, 2019.

[6].N.Siddaiah, et.al, "Sensitivity Enhancement and Optimization of Mems Piezoresistive Microcantilever Sensor for Ultra Mass Detection", International Journal of Innovative Technology and Exploring Engineering (IJITEE) ISSN: 2278-3075, Volume-8, Issue-7S, May 2019

[7].N.Siddaiah, A.Kavya, B.Mounisha, A.Gopi, "Modeling and Performance Analysis of MEMS Based Sensor used for Monitoring Process Chambers in Semiconductor Manufacturing", International Journal of Innovative Technology and Exploring Engineering (IJITEE) ISSN: 2278-3075, Volume-8, Issue-7S, May 2019.

https://doi.org/10.14419/ijet.v7i1.5.9125

[8].N.Siddaiah, G.R.K.Prasad, S. Sai Pravallika, G.V. Sai Prasanna, R. Raja Gopal "Performance of analysis crab leg based RF MEMS switch for defense and aerospace applications", International Journal of Engineering \& Technology,Vol. 7 (1.5) (2018) 71-76.

[9].N.Siddaiah, T.V.Aravind Swami, "Material 
optimization of the novel cantilever based RF MEMS switch for mobile communication" Transactions on Electrical and Electronic Materials, Springer publications, ISSN 1229-7607 Volume 20 Number 4,May,2019.

https://doi.org/10.1007/s42341-019-00120-y

[10].N.Siddaiah.et.al,"Design,simulation and analysis of $U$ shaped and rectangular MEMS based Trile coupled cantilevers",Journal of Scientific and Industrial research,Vol.76,April 2017,235-238

[11].Jithendra Prasad M.G.G., Shameem S., Design and analysis of micro-cantilever-based biosensor for swine flu detection ,2016, International Journal of Electrical and Computer Engineering, Vol: 6, Issue: 3, pp: 1190 - 1196, ISSN 20888708.

https://doi.org/10.11591/ijece.v6i3.9446

[12].Mounica J., Ganesh G.V., Design of a nonvolatile 8T1R SRAM Cell for instant-on operation ,2016, International Journal of Electrical and Computer Engineering, Vol: 6, Issue: 3, pp: 1183 - 1189, ISSN 20888708.

https://doi.org/10.11591/ijece.v6i3.9448

[13].Vinay Kumar B.Y., Shameem S., Ganesh G.V., Optimum resolution of phase frequency detector by CMOS technology for PLL ,2016, International Journal of Engineering and Technology, Vol: 7, Issue: 6, pp: 2240 2247, ISSN 23198613

[14].Murali A., Kakarla H.K., Venkat Reddy D., Integrating FPGAs with trigger circuitry core system insertions for observability in debugging process ,2016, Journal of Engineering and Applied Sciences, Vol: 11, Issue: 12, pp: 2643 - 2650, ISSN 1816949X

[15].Prasad G.R.K., Srinivas Babu P.S., Siddaiah N., Srinivasa Rao K.,Design and simulation of MEMS based sensor for early detection of PD,2017 2016 International Conference on Electrical, Electronics, Communication, Computer and Optimization Techniques, ICEECCOT 2016,Vol:,issue:,pp:366-371,

DOI:10.1109/ICEECCOT.2016.7955247,

ISBN: $9.78151 \mathrm{E}+12$

[16].Ganesh G.V., Srinivasa Rao K., Pavansai Prasad N., Goutham Krishna K., Sravani T., Hemeema K., RF mems based tunable cpw band pass filter integrating periodic circular slot cells,2017 Journal of Advanced Research in Dynamical and Control Systems, Vol:2017, issue:17 Special Issue, pp: 2053-2065, ISSN: 1943023X

[17].Prasad G.R.K., Siddaiah N., Preeti M., Rao K.S., Bhavitha E., Babu P.S.S., Comparative analysis of mems capacitive pressure sensor for detection of tremors in parkinson's disease, 2017 Journal of Theoretical and Applied InformationTechnology, Vol:95, issue:9, pp: 20232030, ISSN: 19928645
[18].Siddaiah N., Prasad G.R.K., Asritha K., Hanumanthu P.V., Anvitha N., Chandra Sekhar T.N.V., Design and model analysis of various shape cantilever based sensors for biomolecules detection,2017 Journal of Advanced Research in Dynamical and Control Systems, Vol:9, issue: Special Issue 16, pp: 476-485, ISSN: 1943023X

[19].Murali Krishna B., Madhumati G.L., Khan H., Dynamically evolvable hardware-software co-design based crypto system through partial reconfiguration,2017 Journal of Theoretical and Applied Information Technology, Vol:95, issue:10, pp: 2159-2169, ISSN: 19928645

[20].Prasad G.R.K., Siddaiah N., Srinivas Babu P.S.,Design and model analysis of circular cantilever sensor for early detection of Parkinson's disease,2017 Journal of Advanced Research in Dynamical and Control Systems,Vol:9, issue:Special Issue 16,pp: 433-444, ISSN: 1943023X.

[21].Yarraguntla N., Tirumala N., Shameem S., Rao K.S. " Detection of Hepatitis viruses (HBV, HAV, HCV) in serum using MEMS based Bio-Sensor “, 2018, International Journal of Engineering and Technology(UAE), Vol: 7 ,Issue: 1.5 ,pp: 42 to:: 50 ,ISSN: 2227524X

[22].Siddaiah N., Roshini T., Sai Krishna V., Prasanth G., Likhith K. .," Performance analysis of cantilever based bio-sensor for pathogen detection ", 2018, Lecture Notes in Electrical Engineering ,Vol: 471 ,Issue: ,pp: 165 to:: 176 , DOI: 10.1007/978-981-10-7329-8_17, ISSN: 18761100 9.78981E+12

[23].Sateesh J., Girija Sravani K., Akshay Kumar R., Guha K., Srinivasa Rao K. .," Design and Flow Analysis of MEMS based Piezo-electric Micro Pump “, 2018, Lecture Notes in Electrical Engineering ,Vol: 471 ,Issue: ,pp: 153 to:: 163, DOI: 10.1007/978-981-10-7329-8_16 ,ISSN: $187611009.78981 \mathrm{E}+12$

[24].Girija Sravani K., Srinivasa Rao K. .," Analysis of RF MEMS shunt capacitive switch with uniform and nonuniform meanders “, 2018, Lecture Notes in Electrical Engineering ,Vol: 471 ,Issue: ,pp: 599

to:: 607, DOI: 10.1007/978-981-10-7329-8_61 ,ISSN: $187611009.78981 \mathrm{E}+12$

[25].Santosh G.S.K., Kumar K.P.M.S., Prasad G.R.K., Srinivasarao K. .," Design and simulation of spinning wheel type crash sensor for the airbag system in car ", 2018, International Journal of Engineering and Technology(UAE) ,Vol: 7 ,Issue: 1.5 ,pp: 7 to:: 12 , ISSN: $2227524 \mathrm{X}$

[26].Shameem S., Srinivas Babu P.S. .," Impedance based MEMS bio-sensor for the detection of colon cancer ", 2018, International Journal of Engineering and Technology(UAE) ,Vol: 7 ,Issue: 1.5 ,pp: 158 to:: 163 , , ISSN: 2227524X .

[27].Shameem S., Prasad G.R.K., Kalyan G., Sri varun H., Babu P.S.S. .," Design and analysis of MEMS based capacitive pressure sensor for the detection of colon cancer “, 2018, Journal of Advanced Research in Dynamical 
N. Siddaiah et al., International Journal of Emerging Trends in Engineering Research, 7(11), November 2019, 670- 676

and Control Systems ,Vol: 10 ,Issue: 2 ,pp: 1434 to:: 1438 ,ISSN: 1943023X.

[28].Kumar M.S., Rao K., Tulasi S.K., Prasad G., Kishore K.H. .," Cantillever based MEMS pressure sensor “, 2018, International Journal of Pharmaceutical Research ,Vol: 10 ,Issue: 4 ,pp: 74 to:: 79 ,DOI: 10.31838/ijpr/2018.10.04.012, ISSN: 9752366

[29]Rekha, V.Chitra, T.Nithya "Sensing Vital Signs of Affected Role and Prioritized Clinical Communication in Ambulance" Volume 6, Issue 4, April (2018)

[30]T Saranya, N Meenakshi, K Priyanka, S Priyanka” Light Fidelity Based Monitoring of Ship Performance and Data Transmission in WSN" Volume 6, Issue 4, April (2018) 